\title{
STUDI KAUSUALITAS GAYA KEPEMIMPINAN DAN MOTIVASI KERJA PADA DINAS KEPENDUDUKAN DAN PENCATATAN SIPIL KOTA-KOTAMOBAGU
}

\author{
Oleh: \\ Devie S. R. Siwij \\ Program Studi Ilmu Administrasi Negara FIS Unima \\ Email: dsiwij@gmail.com
}

\begin{abstract}
ABSTRAK
Tujuan dari penelitian ini adalah untuk mengetahui bagaimana Pengaruh Gaya Kepemimpinan Terhadap Motivsi Kerja pegawai di Dinas Kependudukan dan Pencatatan Sipil Kota Kotamobagu. Untuk menjawab tujuan dari penelitian ini, maka peneliti melakukan penelitian berdasarkan metode Kuantitatif Asosiatif dengan teknik analisis data Regeresi dan korelasi. Hasil penelitian yang dilakukan menunjukan bahwa Berdasarkan hasil perhitungan uji signifikansi dan uji linearitas regresi di atas, dapat disimpulkan bahwa Pengaruh Gaya Kepemimpinan Terhadap Motivsi Kerja pegawai signifikan dan linier. Hal ini dibuktikan karena Fhitung $35.120>\alpha(0,05)$, dengan persamaan regresi $\hat{Y}=9.413+0.435 X$ yang menunjukan bahwa setiap kenaikan satu skor Gaya kepemimpinan akan menyebabkan kenaikan skor Motivasi Kerja Pegawai sebsar 0,435 pada konstanta 9.413.Selanjutnya dilakukan Analisis korelasi digunakan untuk mengetahui ada atau tidak hubungan antara dua variabel dan juga untuk mengetahui seberapa erat hubungan antara variable Gaya Kepemimpinan (X) dan variable Motivasi Kerja (Y). Berdasarkan hasil anaslisis meneujukan bahwa koefisien korelasi r (ryx) sebesar 0.806. Artinya korelasi Gaya Kepemimpinan terhadap Motivasi Kerja tergolong tinggi Selanjutnya untuk mengetahui signifikansi koefisien korelasi $r$ yang telah diperoleh, dilakukan uji signifikansi koefisien korelasi dengan uji t. Dari hasil uji t di atas diperoleh perbandingan nilai thitung 5.926 > ttabel ( $\alpha$ 0.05) 1.725. Dengan demikian $\mathrm{H}_{0}$ ditolak dan $\mathrm{H}_{1}$ diterima. Artinya koefisien korelasi ryx signifikan. Jadi dapat disimpulkan bahwa terdapat pengaruh yang signifikan antara Kepemimpinan (X) terhadap Motivasi Kerja Pegawai (Y). Dari hasil penelitian dan analisis data tersebut dapat disimpulkan bahwa Berdasarkan analisis hasil penelitian menunjukan bahwa Gaya Kepemimpinan memiliki hubungan kausual;itas yang tinggi dengan Motivasi Kerja Pegawai di di Dinas Kependudukan dan Pencatatan Sipil Kota Kotamobagu. Gaya Kepemimipinan juga memiliki berpengaruh secara signifikan dan linier terhadap Motivasi Kerja. Artinya jika nilai kepemipinannya baik maka nilai Motivasi kerja akan naik juga.
\end{abstract}

Kata Kunci: Motivasi Kerja dan Gaya Kepemimpinan 


\section{PENDAHULUAN}

Fungsi pemimpin atau atasan dalam suatu organisasi adalah menggerakan dan mengendalikan prilaku pegawai yang bekerja di dalam organisasi tersebut sehingga mereka dapat melaksanakan kegiatan. secara baik dalam rangkah pencapaian tujuan organisasi. hal ini penting karena tidak semua bawahan atau pengikut mau dengan begitu saja didorong dan diarahkan oleh pemimpin. Jadi, karena pentingnya gaya kepemimpinan ini pada bawahannya, maka perlu diterapkan gaya yang tepat. Gaya kepemimpinan adalah cara seorang pemimpin bersikap, berkomunikasi, dan berinteraksi dengan orang lain dalam mempengaruhi orang untuk melakukan sesuatu. Gaya tersebut bias berbada-beda atas dasar motivasi, kuasa ataupun orientasi terhadap tugas atau orang tertentu diantara beberapa gaya kepemimpinan, terhadap pemimpin yang positif dan negative, dimana perbedaan itu didasarkan pada cara dan upaya mereka memotivasi pegawai/karyawan (Pamungkas, 2012:19).

Dengan demikian fungsi pemimpin atau atasan dalam suatu organisasi diantaranya menggerakan dan mengendalikan prilaku pegawai yang bekerja didalam organisasi tersebut sehingga mereka dapat melaksanakan kegiatan secara baik dalam rangkah pencapaian tujuan organisasi. Agar kondisi demikian tercapai, maka pemahaman terhadap perlunya kepemimpinan harus ditambah dengan pemahaman tentang gaya kepemimpinan.

Dalam kepemimpinan, ada hubungan antara pemimpin dan bawahan terutama bawahan yang dikenakan dalam proses memimpin, potensinya dapat efektif apabila termotivasi kearah pencapaian tujuan. Karena itu berkaitan dengan motivasi ini dapat dikatakan bahwa kepemimpinan dengan bebagai gayanya penting dalam rangkah motivasi bawahan untuk bersamasama dalam pencapaian tujuan. Pemimpin dengan berbagai kewenangannya mempunyai tujuan motivasi bawahannya. Begitu pula sebaliknya bawahan dengan adanya kepemimpinan yang baik dalam organisasi membuat mereka terdorong dan termotivasi searah dengan kepemimpinannya untuk mencapai tujuan organisasi Sedarmayanti (2009:132) mengemukakan bahwa kepemimpinan yang tepat untuk diterapkan adalah gaya kepemimpinan yang dapat memaksimalkan produktivitas, kepuasan kerja, pertumbuhan serta mudah menyesuikan dengan segala situasi yang ada. Demikian halnya di Dinas Kependudukan dan pencatatan sipil Kota Kotamobagu, setiap pegawai yang ada didalamnya mempunyai karakter dan kepribadian, serta sikap dan prilaku yang berbeda-beda. Hal ini tentunya dapat menjadi penyebab lainnya bermacam-macam kebutuhan yang melatar belakangi motivasi mereka dalam bekerja.

Pegawai Negeri Sipil disebut sebagai unsur Aparatur Negara yang mempunyai tugas menyelenggarakan tugas-tugas umum pemerintahan dan pembangunan, dan peranannya disetiap Negara menjadi sangat penting dan sangat menentukan.Hal diatas secara umum ditegaskan dalam UU. No.8 Tahun 1974 jo. UU. No. 43 1999.Tentang perubahan atas UU. No.8 Tahun 1974 tentang pokok-pokok kepegawaian, pasal 1 ayat 1 yang berisih pada dasarnya PNS memiliki, peran dan fungsi utama, antara lain:

1. PNS sebagai pelaksana peraturan perundang-undangan yang telah ditetapkan oleh pemerintah.

2. PNS menjalankan fungsi manajemen pelayanan public

3. PNS sebagai pengelola pemerintahan.

Banyak pegawai yang telah memiliki masa kerja yang cukup lama dan berpengalaman dalam bidang kerjanya. Mereka merasa nyaman dengan suasana kerja yang telah mereka rasakan selama ini, dan juga ada pegawai yang masih kurang melaksanakan tugas dengan baik, dalam hal ini di segi pelayanan yang kurang efektif, kemudian ada juga beberapa pegawai yang kurang disiplin bersifat pilih kasih. Pada sisi lainnya, setiap pegawai yang ada di Dinas 
Kependudukan dan Pencatatan Sipil Kota Kotamobagu tentunya mempunyai persepsi yang tidak sama pada atasannya, dalam hal ini Kepala dinas. Hal ini tentunya akan mengakibatkan adanya persepsi ataupun anggapan yang berbeda-beda dari setiap pegawai terhadap gaya kepemimpinan atasannya, apakah dianggap sangat baik, atau justru sebaliknya.

Tugas pemimpin yang paling sulit yang harus dilakukan adalah bagaimana memotivasi bawahan agar mereka lebih giat bekerja dan penuh tanggung jawab.Motivasi kerja pada dasarnya berpengaruh besar terhadap kinerja, karena kinerja adalah hasil motivasi kerja, kemampuan (abilities), dan peluang (opportunities).

Motivasi disini berarti menggerakan bawahan yang bekerja dalam suatu organisasi atau lembaga pemerintahan. Serta pimpinan organisasi pemerintahan berupaya memotivasi pegawainya dalam bekerja sehingga penyelenggaraan organisasi pemerintahan dapat terlaksana dengan baik.

Penelitian ini perlu dilakukan untuk dapat memotivasi pegawai yang ada di Dinas Kependudukan dan Pencatatan Sipil Kota Kotamobagu khususnya dan pegawai pada umumnya agar mampu meningkatkan iklim kerja yang lebih kondusif dan bergairah lagi dalam bekerja.

Dari uraian di atas ini muncul permasalaham tentang Gaya Kepemimpinan dalam mendorong motivasi kerja pegawai di Kantor Dinas Kependudukan dan Pencatatan Sipil Kota Kotamobagu yang dapat dirumuskan sebagai berikut: (1) Adakah pengaruh Gaya kepemimpinan Terhadap Motivsi Kerja Pegawai Kantor Dinas Kependudukan dan Pencatatan Sipil Kota Kotamobagu? (2). Seberapa besar pengaruh Gaya kepemimpinan Terhadap Motivsi Kerja Pegawai Kantor Dinas Kependudukan dan Pencatatan Sipil Kota Kotamobagu?

Motivasi pada dasarnya berasal dari bahasa latin yaitu "movere" yang artinya "bergerak" atau "mendorong". Berdasarkan kata tersebut maka lahirlah berbagai definisi tentang motivasi. Definisi dasar motivasi menurut Daft dalam Pasolong (2008: 138), adalah dorongan yang bersifat internal atau eksternal pada diri individu yang menimbulkan antusiasme dan ketekunan untuk mengajar tujuan-tujuan spesifik.

Selanjutnya motivasi menurut Luthans (2006:270), adalah sebuah proses yang dimulai dari adanya kekurangan baik secara fisiologis maupun secara psikologis yang memunculkan prilaku atau dorongan yang diarahkan untuk mencapai sebuah tujuan spesifik atau intensif. Prinsip-prinsip Motivasi Menurut Adair (2006: 103), prinsip-prinsip memotivasi ada 8 langkah, antara lain :

1. Pemimpin sendiri harus termotivasi

2. Pilih orang yang bermotivasi tinggi

3. Perlakukan setiap orang sebagai individu

4. Tetapkan sasaran yang realistis dan menantang

5. Ingat akan kemajuan akan termotivasi

6. Ciptakan lingkungan yang memotivasi

7. Berikan hadiah yang adil

8. Berikan pengakuan. Arep Ishak dan Tanjung Hendri (2003:16-17),

Manfaat motivasi yang utama adalah menciptakan gairah kerja, sehingga produktifitas kerja meningkat. Sementara itu, manfaat yang diperoleh karena bekerja dengan orang-orang yang termotivasi adalah pekerjaan dapat diselesaikan dengan tepat. Artinya pekerjaan diselesaikan sesuai standart yang benar dan dalam skala waktu yang sudah ditentukan, serta orang senang melakukan pekerjaannya.

Motivasi merupakan salah satu aspek yang sangat penting dalam menentukan prilaku seseorang termasuk prilaku kerja. Pentingnya motivasi karena motivasi hal yang menyebabkan, menyalurkan, dan mendukung prilaku manusia, supaya mau bekerja giat dan antusias mencapai hasil yang optimal. Motivasi semakin penting karena kapala dinas membagikan pekerjaan pada bawahan untuk dikerjakan dengan baik dan terintegrasi kepada tujuan yang diinginkan.

Menurut Hasibuan dalam buku Manajemen Sumber Daya Manusia (2003 : 
143) yaitu: "Motivasi adalah pemberian daya penggerak yang menciptakan kegerahan kerja seseorang agar mereka mau bekerjasama, bekerja efektif, dan berintegrasi dengan segala daya upayanya untuk mencapai kepuasan.

Berdasarkan pendapat para ahli di atas maka dapat diartikan bahwa motivasi merupakan pendorong yang ada dalam diri individu yang memberikan daya penggerak untuk melakukan sesuatu dengan sebaik mungkin. Apabila individu tersebut memiliki motivasi yang tinggi maka dia akan mencapai kepuasan dalam melakukan pekerjaan, karena tujuan yang akan dicapai dan yang diinginkan oleh instansi pemerintahan dapat terwujud. Motivasi mempersoalkan bagaimana caranya menggerakan daya dan potensi bawahan, agar mau bekerjasama secara produktif berkasil mencapai dan mewujudkan tujuan yang telah ditentukan.

Menurut Ernest J. Mc Cormick yang dikutip oleh Mangkunegara (2005:94) menyatakan bahwa motivasi kerja didefinisikan sebagai kondisi yang berpengaruh membangkitkan, mengarahkan dan memelihara prilaku yang berhubungan dengan lingkungan kerja.

Indikator-Indikator yang digunakan dalam variable motivasi kerja adalah sebagai berikut:

1. Tingkat tanggung jawab terhadap pekerjaan

2. Dorongan organisasi terhadap anggotanya

3. Kebutuhan akan aktualisasi diri

4. Kebutuhan afiliasi

5. Kebutuhan penghargaan.

Pada bagian lain, konsep "pemimpin" beasal dari kata asing "leader" dan "kepemimpin" dari "leadership", dan juga kepemimpinan berasal dari kata pimpin yang memuat dua hal pokok yaitu : pemimpin sebagai subjek dan yang dipimpin sebagai objek. Kasta pimpin mengandung pengertian mengarahkan, membina atau mengatur, menuntun dan juga menentukan ataupun mempengaruhi. Pemimpin mempinyai tanggung jawab baik secara fisik maupun spiritual terhadap keberhasilan aktivitas kerja dari yang dipimpin, sehingga menjadi pemimpin itu tidakmuda dan tidak akan setiap orang mempunyai kesamaan di dalam menjalankan ke-pemimpinannya.

Dubrin (2005:3) dalam bukunya Leadership mengemukakan bahwa kepemimpinan itu adalah upaya mempengaruhi banyak orang melalui komunikasi untuki mencapai tujuan, cara mempengaruhi orang dengan petunjuk atau perintah, tindakan yang menyebabkan orang menimbulkan perubahan positif, kekuatan dinamis penting yang memotivasi dan mengkoordinasikan organisasi dalam rangkah mencapai tujuan, kemampuan dan dukungan diantara bawahan agar tujuan organisasional dapat dicapai.

Siagian (2008:62) dalam bukunya Manajemen Sumber Daya Manusia mengemukakan bahwa "Kepemimpinan adalah kemampuan seseorang untuk mempengaruhi orang lain (para bawahannya) sedemikian rupa sehingga orang lain itu mau melakukan kehendak pemimpin meskipun secara pribadi hal itu mungkin tidak disenangi.

Nimran (2004 : 64) mengemukakan bahwa "kepemimpinan atau leadership adalah merupakan suatu proses mempengaruhi prilaku orang lain agar berprilaku seperti yang akan dikehendaki". Robins (1996:39) mengemukakan bahwa "kepemimpinan adalah sebagian kemampuan untuk mempengaruhi suatu kelompok kearah tercapainya suatu tujuan".

Kepemimpinan adalah keseluruhan proses mempengaruhi, mendorong, mengajak, menggerakkan dan menuntun orang lain dalam proses agar berpikir, dan bertindak sesuai dengan aturan yang berlaku dalam rangka mencapai tujuan yang telah ditetapkan. Misalnya Kepala Dinas memotivasi pegawainya, agar mereka mau melaksanakan tugasnya masing-masing demi tercapainya tujuan yang telah ditetapkan. Adapun unsure-unsur kepemimpinan, yaitu: orang yang memimpin, orang-orang yang dipimpin, Kegiatan atau tindakan 
penggerakan untuk mencapai tujuan serta tujuan yang akan dicapai.

Keith Devis (dalam Thoha, 2010:33:34) merumuskan empat sifat umum yang mempunyai pengaruh terhadap keberhasilan kepemimpinan organisasi yaitu kecerdasan (inteligensia), kedewasaan dan keluasan hubungan social, motivasi diri dan dorongan berprestasi serta sikap-sikap hubungan kemanusiaan.

Di dalam kepemimpinan sering terjadi berbagai gaya seorang pemimpin untuk mengimplementasikan tugas kepemimpinannya. Gaya kepemimpinan dapat didefinisikan sebagai pola tingkah laku yang dirancang untuk mengintegrasikan tujuan organisasi dan tujuan individu untuk mencapai suatu tujuan tertentu (Heidjrachman dan Suad Husnan, 2002:224).

Melalui gaya kepemimpinan yang dimiliki seorang pemimpin, ia akan mentransfer beberapa nilai seperti penekanan kelompok, dukungan dari orangorang/karyawan, toleransi terhadap resiko dan sebagainya. Pada sisi lain, pegawai akan membentuk suatu persepsi sudyektif mengenai dasar-dasar nilai yang ada dalam organisasi sesuai dengan nilai-nilai yang ingin disampaikan pemimpin melalui gaya kepemimpinan.

Gaya kepemimpinan ada bermacammacam yaitu:

\section{Gaya Kepemimpinan Otokrasi}

Gaya kepemimpinan otokrasi ditandai dengan ketergantungan kepada yang berwenang, yang menganggap bahwa orangorang tidak akan melakukan apa-apa jika diperintahkan oleh pemimpin.

2. Gaya Kepemimpinan Demokratis

Gaya kepemimpinan demokratis merupakan gaya kepemimpinan yang dipakai oleh mereka yang percaya bahwa untuk memotivasi orang dalam bekerja adalah dengan melibatkan mereka dalam setiap pengambilan keputusan.

\section{Gaya Kepemimpinan Laissez}

Gaya kepemimpinan laissez yaitu pemimpin hanya melaksanakan fungsi pemeliharaan saja karena semua tugas hanya di berikan kepada bawahan .

Setiap pemimpin tentunya memiliki gaya masing-masing untuk diterapkan pada setiap organisasi tempat mereka bekerja. Veithzal Rivai, (2004:64).

Veithzal Rivai Berpendapat bahwa "Gaya kepemimpinan adalah pola menyeluruh dari tindakan seorang pemimpin, baik yang tampak maupun yang tidak tampak oleh bawahannya". Gaya kepemimpinan menggambarkan kombinasi yang konsisten dari falsafah, ketrampilan, sifat, dan sikap yang mendasari prilaku seseorang. Indikator-Indikator Gaya Kepemimpinan:

1. Visi dan misi, menanamkan kebanggaan, meraih penghormatan dan kepercayaan.

2. Mendorong Intelegensi, rasionalitas dan pemecahan masalah secara hati-hati.

3. Memberikan perhatian pribadi, melayani secara pribadi, melati dan menasehati.

4. Menjalankan peraturan konstraktual antara penghargaan dan usaha, menjanjikan penghargaan untuk kinerja yang bagus dan mengakui pencapaian yang diperoleh.

5. Melepaskan tanggung jawab dan menghindari pengambilan keputusan.

Berdasarkan uraian di atas, maka dapat disusun kerangka pikir yang digunakan dalam penelitian ini dan sekaligus sebuah model untuk diuji secara empiris. Hal tersebut dapat dilihat pada Gambar 1 berikut.

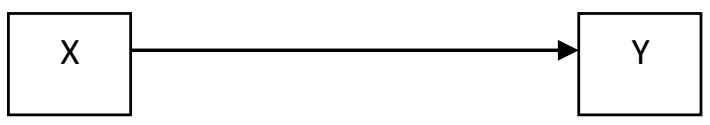

\section{METODE PENELITIAN}

Dalam penelitian ini saya menggunakan pendekatan penelitian Kuantitatif, yaitu menggunakan data yang dapat di hitung untuk menghasilkan penafsiran kuantitatif yang kuat. Jadi data kuantitatif adalah nilai dari perubahan yang dapat dinyatakan dalam bentuk angka-angka (statistik).Dalam penelitian ini, peneliti menggunakan metode penelitian Kuantitatif Asosiatif, dimana penelitian ini bertujuan 
untuk mengetahui hubungan antara dua variabel atau lebih. Dalam penelitian ini peneliti melakukan analisa terhadap 2 variabel,yaitu variable (X) "Gaya Kepemimpinan" dan (Y) "Motivasi Kerja Pegawai" di Dinas Kependudukan dan Pencatatan Sipil Kota Kotamobagu.

Dalam penelitian ini dihasilkan indikator-indikator variabel yang diturunkan dari beberapa teori tentang konsep Gaya Kepemimpian dan Motivasi Kerja Pegawai, Dalam penelitian ini mengikuti pola berpikir deduktif, dimana terjadi proses pengamatan kemudian hipotesis, selanjutnya pengumpulan data lalu pengujian hipotesis dan terakhir kesimpulan. Adapun populasi dalam penelitian ini adalah keseluruhan pegawai Dalam penelitian ini saya menggunakan pendekatan penelitian Kuantitatif, yaitu menggunakan data yang dapat di hitung untuk menghasilkan penafsiran kuantitatif yang kuat. Jadi data kuantitatif adalah nilai dari perubahan yang dapat dinyatakan dalam bentuk angka-angka (statistik). Dalam penelitian ini, peneliti menggunakan metode penelitian Kuantitatif Asosiatif, dimana penelitian ini bertujuan untuk mengetahui hubungan antara dua variabel atau lebih.

Dalam penelitian ini peneliti melakukan analisa terhadap 2 variabel,yaitu variable (X) "Gaya Kepemimpinan" dan (Y) "Motivasi Kerja Pegawai" di Dinas Kependudukan dan Pencatatan Sipil Kota Kotamobagu. Sedangkan sampel didasarkan pada pendapat Soegiyono (2013), di mana semua populasi dijadikan sampel nila populasinya di bawah 100 .

\section{HASIL PENELITIAN}

Berdasarkan hasil penelitian yang diperoleh melalui analisis data yang telah dilakukan, dalam bagian ini disajikan pembahasan terhadap hasil-hasil penelitian tersebut, yaitu sebagai berikut:

\section{Motivasi Kerja Pegawai}

Secara umum pegawai Kependudukan dan Pencatatan Sipil Kota Kotamobagu memiliki motivasi kerja yang cukup baik dengan 76,93 persen atau total skor sebesar 517 dari total maksimal skor motivasi kerja yang berjumlah 672 sesuai skala pengukuran rating scale. Motivasi untuk bekerja mencapai tujuan yang diinginkan merupakan skor tertinggi yang diperoleh dengan angaka 88,9 persen.

Hal ini menunjukan bahwa pegawai Kependudukan dan Pencatatan Sipil Kota Kotamobagu dalam bekerja selalu berharap untuk mencapai tujuan dari pekerjaan mereka.

Berdasarkan data penelitian yang

\section{Korelasi Gaya Kepemimpinan dan} Motivasi Kerja Pegawai

\begin{tabular}{|cc|c|c|}
\hline & & $\begin{array}{c}\text { Gaya } \\
\text { Kepemipinan }\end{array}$ & $\begin{array}{c}\text { Motivasi } \\
\text { Kerja }\end{array}$ \\
\hline $\begin{array}{ccc}\text { Gaya } \\
\text { Kepemipinan }\end{array}$ & $\begin{array}{c}\text { Pearson } \\
\text { Correlation } \\
\text { Sig. (2-tailed) }\end{array}$ & 1 & $.806^{* *}$ \\
Motivasi Kerja & $\mathrm{N}$ & 21 & .000 \\
& $\begin{array}{c}\text { Pearson } \\
\text { Correlation }\end{array}$ & $.806^{* *}$ & 1 \\
& Sig. (2-tailed) & .000 & \\
& $\mathrm{~N}$ & 21 & 21 \\
\hline
\end{tabular}

tegolong rendah dibandingkan dengan indikator yang lain dalam variable motivasi kerja pegawai adalah tentang mencari kepuasan kerja dan minat dalam pekerjaan yang di geluti. Supardi dan Anwar (2004:47) mengatakan motivasi adalah keadaan dalam pribadi seseorang yang mendorong keinginan individu untuk melakukan kegiatan-kegiatan tertentu guna mencapai tujuan. Motivasi yang ada pada seseorang akan mewujudkan suatu prilaku yang diarahkan pada tujuan mencapai sasaran kepuasan. Jadi, motivasi bukanlah yang dapat diamati tetapi adalah hal yang dapat disimpulkan adanya karena sesuatu prilaku yang tampak.

Arep Ishak dan Tanjung Hendri (2003:16-17), Manfaat motivasi yang utama adalah menciptakan gairah kerja, sehingga produktifitas kerja meningkat.Sementara itu, manfaat yang diperoleh karena bekerja dengan orang-orang yang termotivasi adalah pekerjaan dapat diselesaikan dengan tepat. Artinya pekerjaan diselesaikan sesuai standart yang benar dan dalam skala waktu 
yang sudah ditentukan, serta orang senang melakukan pekerjaannya.

Menurut Hasibuan dalam buku Manajemen Sumber Daya Manusia (2003: 143) yaitu: "Motivasi adalah pemberian daya penggerak yang menciptakan kegerahan kerja seseoirang agar mereka mau bekerjasama, bekerja efektif, dan berintegrasi dengan segala daya upayanya untuk mencapai kepuasan.

Berdasarkan pendapat para ahli di atas maka dapat diartikan bahwa motivasi merupakan pendorong yang ada dalam diri individu yang memberikan daya penggerak untuk melakukan sesuatu dengan sebaik mungkin. Apabila individu tersebut memiliki motivasi yang tinggi maka dia akan mencapai kepuasan dalam melakukan pekerjaan, karena tujuan yang akan dicapai dan yang diinginkan oleh instansi pemerintahan dapat terwujud.

\section{Kepemimpinan}

Model Summary ${ }^{b}$

\begin{tabular}{|r|r|r|r|r|}
\hline Model & \multicolumn{1}{|c|}{$\mathrm{R}$} & $\mathrm{R}$ Square & $\begin{array}{l}\text { Adjusted R } \\
\text { Square }\end{array}$ & $\begin{array}{r}\text { Std. Error of } \\
\text { the Estimate }\end{array}$ \\
\hline 1 & $.806^{\mathrm{a}}$ & .649 & .630 & 1.993 \\
\hline
\end{tabular}

a. Predictors: (Constant), Gaya Kepemipinan

b. Dependent Variable: Motivasi Kerja

Kepemimpinan yang ditunjukan oleh Pimpinan Dinas Kependudukan dan Pencatatan Sipil Kota Kotamobagu dapat dikatakan cukup baik dalam mempengaruhi bawahan, dimana sebesar 72,92 persen nilai Kepemimpinan dari total sempurna sebesar 1008 yang direspon oleh bawahan dalam mendorong motivasi kerja mereka. Adapun nilai tertinggi untuk setiap indikoator dari kepemimpinan yang diteliti adalah tentang visi dan misi dari pemimpin yang ada saat ini dengan mencapai skor persentase sebesar 82,14 persen. Hal ini menegaskan bahwa respon paling tinggi terhadap gaya kepemimpinan yang ditunjukan oleh pemimpin saat ini adalah soal-visi dan misinya dalam mencapai tujuan organisasi.
Masalah perhatian terhadap bawahan merupakan skor terendah yaitu sebesar 67,86 persen dari total skor sempuran yang tersedia. Namun demikian hal ini masih dinilai cukup baik.

Veithzal Rivai, (2004:64) Berpendapat bahwa "Gaya kepemimpinan adalah pola menyeluruh dari tindakan seorang pemimpin, baik yang tampak maupun yang tidak tampak oleh bawahannya”. Gaya kepemimpinan menggambarkan kombinasi yang konsisten dari falsafah, ketrampilan, sifat, dan sikap yang mendasari prilaku seseorang.

Dengan demikian secara keseluruhan setiap indikator dari kepemimpinan harus menjadi perhatian pimpinan dalam memotivasi pegawai di Kependudukan dan Pencatatan Sipil Kota Kotamobagu untuk bekerja secar maksimal.

\section{KESIMPULAN DAN SARAN}

\section{Kesimpulan}

1. Motivasi Kerja Pegawai pada Kependudukan dan Pencatatan Sipil Kota Kotamobagu dipengaruhi oleh kepemimpinan yang dilakukan oleh kepal dinas. Hal ini berarti semakin efektifnya gaya kepemimpina yang ditunjukan oleh pemimpi maka akan meningkatkan motivasi kerja pegawai.

2. Secara umum pegawai Dinas Kependudukan dan Pencatatan Sipil Kota Kotamobagu memiliki motivasi kerja yang cukup baik dengan 76,93 persen atau total skor sebesar 517 dari total maksimal skor motivasi kerja yang berjumlah 672 sesuai skala pengukuran rating scale. Motivasi untuk bekerja mencapai tujuan yang diinginkan merupakan skor tertinggi yang diperoleh dengan angaka 88,9 persen.

3. Pegawai Dinas Kependdukan dan Catatan Sipil Kota Kotamobagu dalam bekerja selalu berharap untuk mencapai tujuan dari pekerjaan mereka.

\section{B. Saran}

1. Dalam melaksanakan kepemimpin, kepala dinas harus juga fokus pada 
indikator-indikator kepemimpinan yang sudah berjalan secara efektif misalnya tentang penekanan visi dan misi sebagai pemimpin dalam melaksankan pekerjaan organisasi agar nilai motivasi kerja pegawai dapat meningkat..

2. Dalam melaksanakan pekerjaan, para pegawai harus memberikan masukan kepada pimpinan soal minat dan kompetensinya dalam pekerjaan yang dilakukan sehingga dapat menjadi refernsi untuk menempatkan pegawai dibidang yang sesuai.

3. Dalam hal adanya masalah pribadi yang sangat mengganggu motivasi kerja pegawai, haruslah dikomunikasikan dengan pimpinan. Termasuk juga niat dalam mengembangkan karir dan kemampuan lewat kesempatan mengikuti berbagai pelatihan.

\section{DAFTAR PUSTAKA}

Adair, John, 2006. Kepemimpinan Yang Memotivasi. Jakarta : PT. Gramedia Pustaka Utama

Arep, Ishak dan Tanjung Hendri. 2003. Manajemen Motivasi. Jakarta: PT. Gramedia Widiasarana Indonesia.

Dubrin Andrew J. 2005. Leadership (Terjemahan). Edisi Kedua. Jakarta: Prenada Media.

Hasibuan, M. (2003). Manajemen Sumber Daya Manusia, Jakarta : PT.Bumi Aksara.

Heidjrachman Dan Husnan,Suad. 2002. Manajemen Personalia. Penerbit: BPFE UGM, Yogyakarta.

Luthans, Fred. 2006. Perilaku Organisasi, (Alih Bahasa V.A Yuwono, dkk), Edisi Bahasa Indonesia, Yogyakarta: ANDI Manajemen Universitas Muhammadiyah Surakarta.

Mangkunegara, A. Prabu.(2005). Manajemen Sumber Daya Manusia Perusahaan. Cetakan keenam.Bandung : PT. Remaja Rosdakarya.

Nimran, Umar. 2004, Perilaku Organisasi, Erlangga, Jakarta.

Pamungkas Sutan. (2012). Menjadi Pemimpin Dasyat Fenomental. Araska. Yogyakarta.

Rivai. Veithzal.(2004). Kepemimpinan dan Prilaku Organisasi. Edisi kedua. Jakarta : PT. Raja Grafindumbero Persada.

Robbins, Stephen P., 1996. Perilaku Organisasi, Konsep, Kontroversi dan Aplikasi. Alih Bahasa: Hadyana Pujaatmaka. Edisi Keenam. Penerbit PT. Bhuana Ilmu Populer, Jakarta.

Sedarmayanti. (2009). Sumber Daya Manusia dan Produktivitas Kerja. Bandung: CV. Mandar Maju.

Thoha, Miftah, 2010. Kepemimpinan Dalam Manajemen, Jakarta : Rajawali Pers

Siagian, Sondang P. 2008. Manajemen Sumber Daya Manusia. PT Bumi Aksara: Jakarta

Siregar, Syofian, 2012. Statistik Parametik untuk Penelitian Kuantitatif. Bumi Aksara Jakarta

Sugiyono, 2010, Metode Penelitian Kualitatif, Kuantitatif, $R \& D$. Bandung: ALFABETA

UU.Nomor 43 Tahun 1999 tantang perubahan atas UU. Nomor 8 Tahun 1974 tentang pokokpokok kepegawaian, pasa 1 ayat 1 yang berisih Pada dasarnya PNS memiliki peran dan fungsi utama. 